\title{
Pembelajaran Maharah Kitabah di Madrasah Ibtidaiyyah Tahfizh SAQU Ibnu Mas'ud Godean Yogyakarta
}

\author{
${ }^{1 *}$ Mega Primaningtyas, ${ }^{2}$ Annisa Lathifah \\ 12STAI Masjid Syuhada Yogyakarta \\ 1*Megaprimaningtyas@hotmail.com
}

$$
\begin{aligned}
& \text { الخلاصة: تهدف هذه الدراسة إلى تحديد تعلم مهارة الكتاب والعوامل الداعمة والمثبطة لتعلم محارات الكتابة العربية في مدرسة ابتدائية }
\end{aligned}
$$

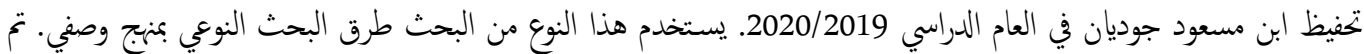

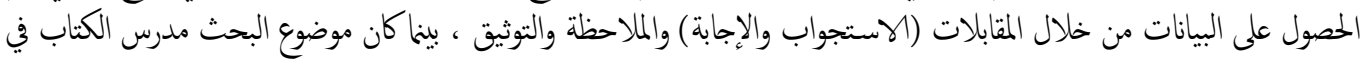

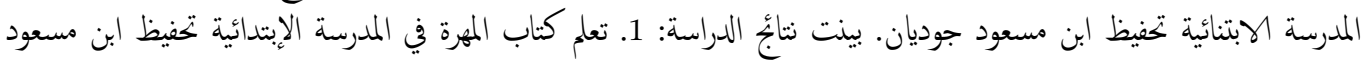

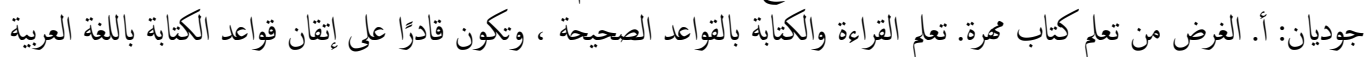

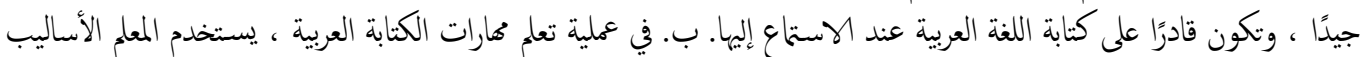

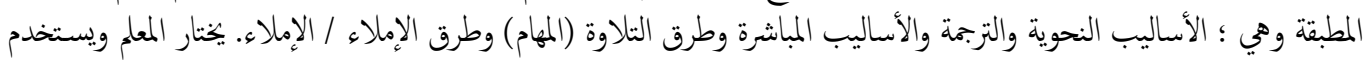

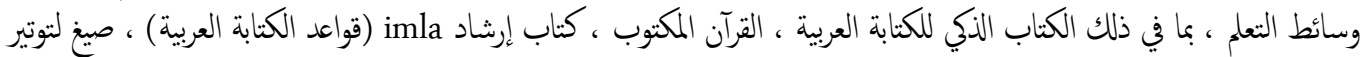

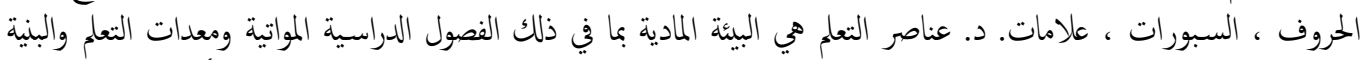

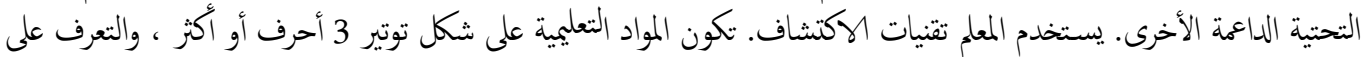

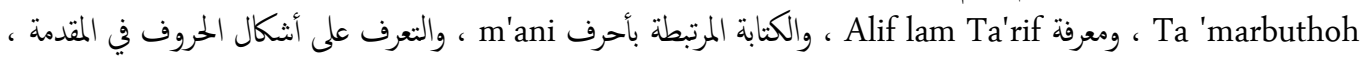

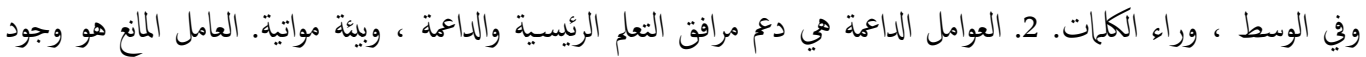

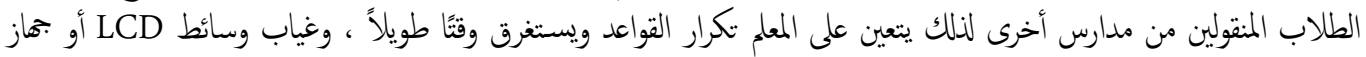

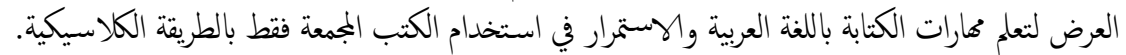

$$
\begin{aligned}
& \text { الكلمات المفتاحية: التعلم ، محارة كتابه ، المدرسة الإبتدائية }
\end{aligned}
$$

Abstract: This study aims to determine the learning of maharah kitabah and the supporting and inhibiting factors for learning Arabic writing skills at Madrasah Ibtidaiyyah Tahfizh Ibnu Mas'ud Godean in the 2019/2020 school year. This type of research uses qualitative research methods with a descriptive approach. The data obtained by using interviews (questioning and answering), observation and documentation, while the research subject was the teacher of the book at Madrasah Ibtidaiyyah Tahfizh Ibnu Mas'ud Godean. The results of the study show: 1. Learning Maharah Kitabah at Madrasah Ibtidaiyyah Tahfizh Ibnu Mas'ud Godean are: a. The purpose of learning maharah kitabah; learn to read and write with the correct rules, master the rules of writing Arabic well, and write Arabic when listened to. b. In learning Arabic writing skills, the teacher uses the methods applied, namely, grammatical and translation methods, direct methods, recitation methods (tasks) and imla'/dictation methods. c. The teacher selects and uses learning media, including the Arabic Writing SmartBook, the Written Al-Qur'an, an imla' guidebook (the rules of Arabic writing), formulas for stringing letters, blackboards, markers. d. The learning elements are the physical environment, including conducive classrooms, learning equipment and other supporting infrastructure. The teacher uses discovery techniques. Learning materials are in the form of stringing three or more letters, getting to know Ta' marbuthoh, knowing Alif lam ta'rif and writing connected with the letters ma'ani, recognizing the forms of letters in front, in the middle and behind words. 2 . The supporting factors are the support of the 
principal, supportive learning facilities, a conducive environment. The inhibiting factor is transfer students from other schools, so the teacher has to repeat the rules, and it takes a long time, the absence of LCD or projector media for learning Arabic writing skills and still using only package books with the classical method.

Keywords: Learning, Maharah Kitabah, Madrasah Ibtidayyah

\section{PENDAHULUAN}

Bahasa Arab hingga saat ini merupakan salah satu bahasa yang masih bertahan dan tetap mendunia, posisinya sejajar dengan bahasa Inggris dan Prancis. Bahasa Arab tidak dapat dipisahkan dari kehidupan umat muslim. Pada zaman sekarang bahasa Arab sudah mulai banyak digunakan sebagai bahasa Internasional selain bahasa Inggris. Bahasa Arab memiliki keistimewaan diantara bahasa-bahasa yang lain karena Allah menurunkan Al-Qur'an dalam bahasa Arab. Selain bahasa Al-Qur"an, Hadits-hadits dan kitab lainnya menggunakan bahasa Arab, bahasa Arab juga merupakan bahasa ahli surga. Yang mana Allah yang memilihkan bahasa itu untuk digunakan bercakap-cakap di dalam surga. ${ }^{1}$

Pelajaran kemampuan menulis bahasa Arab di Madrasah Ibtidaiyyah Tahfizh Ibnu Mas'ud Yogyakarta merupakan mata pelajaran yang diharapkan mampu mengembangkan keterampilan menulis sesuai dengan kaidah yang baik dan benar. Karena keterampilan menulis merupakan bagian penting dalam pembelajaran bahasa Arab.

Berdasar wawancara yang penulis lakukan dengan guru keterampilan menulis bahasa Arab, pembelajaran menulis bahasa Arab di Madrasah Ibtidaiyyah Tahfizh Ibnu Mas'ud memiliki banyak kendala antara lain ialah belum pahamnya siswa mengenai penulisan huruf Arab, beberapa siswa tidak bergairah dan tidak semangat dalam pembelajaran maharah kitabah, kurangnya motivasi belajar siswa untuk menulis Arab. Siswa juga mengalami kesulitan dalam penulisan yaitu pada saat guru mendikte kalimat dalam bahasa Arab, siswa bingung membedakan huruf mana yang penulisannya harus ataupun yang dipisah, karena membedakan huruf sesuai makhraj (tempat keluarnya huruf) berpengaruh dengan penulisan huruf.

Dengan latar belakang di atas, maka peneliti merasa perlu menganalisis lebih lanjut terkait masalah pembelajaran maharah kitabah sehingga kedepannya dapat menjadi evaluasi bagi pendidik dan dapat diperbaiki terkait permasalahan kemampuan menulis bahasa Arab yang ada di Madrasah Ibtidaiyyah Tahfizh Ibnu Mas'ud Godean. Dengan demikian peneliti akan melaksanakan penelitian yang berjudul “Pembelajaran Maharah Kitabah Di Madrasah Ibtidaiyyah Ibnu Mas'ud SAQU Godean Yogyakarta"

${ }^{1}$ M. Feri Fauzi dan Irma Anindiati, E learning dalam Pembelajaran Bahasa Arab, (Malang : UMM, 2020), 13 


\section{METODE PENELITIAN}

Metode penelitian adalah suatu kegiatan ilmiah yang dilakukan secara bertahap dimulai dengan penentuan topik, pengumpulan data dan menganalisis data, sehingga nantinya diperoleh suatu pemahaman dan pengertian atas topik, gejala atau isu tertentu. ${ }^{2}$ Metode penelitian digunakan untuk mempermudah pengumpulan data dan analisis data, serta mengarahkan pada penelitian yang yang relevan.

Jenis penelitian yang digunakan dalam penelitian ini adalah penelitian bersifat kualitatif dengan pendekatan deskriptif. Penelitian kualitatif adalah penelitian yang menggunakan latar alamiah dengan maksud menafsirkan fenomena yang terjadi dan dilakukan dengan jalan melibatkan berbagai metode yang ada. Dapat disimpulan bahwa penelitian kualitatif adalah pengumpulan data pada suatu latar alamiah dengan maksud menafsirkan fenomena yang terjadi dimana peneliti adalah sebagai instrumen kunci, pengambilan sampel sumber data dilakukan secara purposive dan snowbaal, teknik pengumpulan dengan trianggulasi (gabungan), analisis data bersifat indukti/kualitatif, dan hasil penelitian kualitatif lebih menekankan makna daripada generalisasi. ${ }^{3}$ Pendekatan dekriptif yaitu dimana penelitian yang dilakukan untuk mengeksplorasi atau memotret situasi sosial yang akan diteliti secara menyeluruh, luas dan mendalam. ${ }^{4}$

Penelitian ini mengambil lokasi di Madrasah Ibtidaiyyah Tahfizh SAQU Ibnu Mas"ud, Tebon, XIII, RT.004/RW.30, Sleman, Daerah Istimewa Yogyakarta. Waktu penelitian dilaksanakan selama 9 bulan dimulai November 2019 - Agustus 2020. Adapun subjek penelitian adalah sumber data dari mana data dapat diperoleh baik berupa orang, tempat, maupun benda. Subjek penelitian dalam pemelitian ini adalah informan. Informan adalah seseorang yang mengetahui objek penelitian.

Dalam penelitian pembelajaran maharah kitabah ini, subjek penelitian yang diambil adalah satu guru bidang studi kemampuan menulis bahasa Arab guna memperoleh keterangan tentang proses pembelajaran kemampuan menulis bahasa Arab serta faktor pendukung maupun penghambat pembelajaran tersebut.

Data dalam penelitian ini dibagi menjadi 2 yaitu data primer dan data sekunder. Data primer, yakni sumber data primer diperoleh langsung dari subjek dan informan penelitian dengan menggunakan panduan wawancara dengan guru bidang studi menulis bahasa Arab Madrasah Ibtadiyyah Ibnu Mas'ud Godean Yogyakarta. Data sekunder berupa data yang diperoleh atau dikumpulkan oleh orang yang melakukan

\footnotetext{
${ }^{2}$ Conny R. Semiawan, Metode Penelitian Kualitatif, (Jakarta: Grasindo, 2011), 2

${ }^{3}$ Albi Anggito dan Johan Setiawan, Metode Penelitian Kualitaif, (Sukabumi: CV Jejak, 2018), 7-8

${ }^{4}$ Sugiyono, Metode Penelitian Kombinasi (mixed method),(Bandung:Alfabeta, 2013), 290
} 
penelitian dari sumber-sumber yag telah ada. ${ }^{5}$ Data yang digunakan dalam untuk informasi primer yang diperoleh yaitu dari bahan pustaka, literatur, penelitian terdahulu, buku, dan lain sebagainya.

Teknik Pengumpulan Data berupa; 1) Observasi, Metode ini penulis gunakan untuk mengamati proses pembelajaran kemampuan menulis bahasa Arab. Observasi lainnya adalah untuk mengamati faktor penghambat dan pendukung pembelajaran kemampuan menulis bahasa Arab; 2) Dokumentasi. Metode dokumentasi adalah informasi yang berasal dari catatan penting baik dari lembaga atau organisasi maupun dari perorangan. Dokumentasi penelitian ini merupakan pengambilan gambar oleh peneliti untuk memperkuat hasil penelitian. ${ }^{6}$ Dokumentasi yang digunakan dalam penelitian ini diantaranya RPP, Silabus, Dokumen evaluasi, dan dokumen penujnjang lainnya; 3) Wawancara. Wawancara yang akan penulis lakukan bersifat bebas terpimpin yaitu wawancara secara bebas tetapi terpimpin karena dengan wawancara bebas terpimpin ini akan diperoleh data yang mendalam sekaligus mengarah pada pokok permasalahan. Wawancara ini dilakukan kepada guru bidang studi kemampuan menulis bahasa Arab. Metode ini digunakan untuk memperoleh informasi tentang proses pembelajaran maharah kitabah serta faktor pendukung dan penghambatnya.

\section{PEMBAHASAN}

Untuk mengetahui pembelajaran kemampuan menulis bahasa Arab di Madrasah Ibtidaiyyah Ibnu Mas'ud Godean Yogyakarta, berikut ini penulis akan mendiskripsikan hasil temuan penulis melalui hasil wawancara dengan guru mata pelajaran kemampuan menulis bahasa Arab dan observasi kegiatan belajar mengajar berlangsung.

1. Pembelajaran Kemampuan Menulis Bahasa Arab Di Madrasah Ibtidaiyyah Ibnu Mas'ud Godean Yogyakarta adalah sebagai berikut:

a. Tujuan Pembelajaran Kemampuan Menulis Bahasa Arab di MIT Ibnu Mas'ud Yogyakarta.

Tujuan pembelajaran merupakan salah satu aspek yang perlu dipertimbangkan dalam merencanakaan pembelajaran. Sebab segala kegiatan pembelajaran muaranya pada tercapainya tujuan tersebut. Dalam setiap aktivitas, bisa dikatakan sudah pasti memiliki arah, tujuan yang akan dicapai. Untuk mencapai tujuan tersebut diperlukan sebuah tindakan yang disengaja supaya memiliki nilai baik bersifat pribadi atau

5 M. Iqbal Hasan, Pokok-pokok Materi Metodologi Penelitian dan Aplikasinya, (Bogor:Ghalia Indonesia, 2002), 85

${ }^{6}$ Albi Anggito dan Johan Setiawan, Metode Penelitian Kualitaif,(Sukabumi: CV Jejak, 2018), 255 
individu maupun sosial/untuk orang banyak. Terlebih lagi aktivitas yang dimaksud memiliki keterkaitan antara satu individu yang lain.

Sesuai dengan hasil wawancara dengan guru mata pelajaran maharah kitabah, dapat diketahui bahwa tujuan pembelajaran kemampuan menulis Arab antara lain adalah:

1) Merupakan kewajiban seorang muslim adalah belajar membaca dan menulis dengan kaidah yang benar.

2) Siswa mampu menguasai kaidah-kaidah penulisan bahasa Arab dengan baik. Kelak jika harus berada di majlis ulama bisa menulis Arab sesuai dengan materi yang dibawakan.

3) Siswa mampu menulis Arab jika didektekan atau didengarkan.

b. Media yang digunakan dalam pembelajaran kemampuan menulis bahasa Arab MIT Ibnu Mas'ud Yogyakarta.

Media pembelajaran, merupakan salah satu alat bantu dalam proses pembelajaran yang mendukung tercapainya tujuan pembelajaran. Media pembelajaran merupakan sarana komunikasi dalam bentuk cetak maupun dengar. Karena dapat membantu proses komunikasi dalam pembelajaran. Oleh karena itu media pembelajaran menempati posisi yang cukup penting. Tanpa menggunakan media, komunikasi yang tejadi akan tidak maksimal dan proses pembelajaran juga akan berlangsung secara tidak optimal.

Hal penting yang dilakukan oleh guru mata pelajaran kemampuan menulis bahasa Arab adalah memahami tentang pentingnya media dalam sebuah pembelajaran yang disesuaikan dengan tujuan pembelajaran. Media pembelajaran merupakan alat bantu berupa fisik maupun nonfisik yang sengaja digunakan sebagai perantara antara guru dan siswa dalam memahami materi pembelajaran agar lebih efektif dan efisien. Media pembelajaran yang baik dapat membantu materi pembelajaran lebih cepat diterima siswa dengan utuh serta menambah minat siswa untuk belajar lebih lanjut.

Terkait macam dan bentuk media pembelajaran, peneliti mendapat informasi melalui wawancara guru sekaligus mengetahui proses pembelajaran melalui obsevasi ketika pembelajaran menulis bahasa Arab berlangsung. Dalam pembelajaran kemampuan menulis bahasa Arab ini, guru menyiapakan buku panduan menulis bahasa Arab berupa 4 paket Buku Pintar Menulis Arab karya Fajriyah Na'im S.S yang 
akan disesuaikan dengan kemampuan masing-masing siswa, buku paket Al Qur'an Tulis metode Follow The Line, buku panduan imla' (kaidahkaidah menulis Arab) karya Muhammad Madqur, rumus kaidah merangkai huruf (huruf disambung dan dipisah), papan tulis, spidol.

Media pembelajaran akan lebih bermanfaat jika media tersebut disesuaikan dengan materi dan tujuan pembelajaran yang telah disiapkan dengan baik.

c. Metode yang digunakan dalam pembelajaran maharah kitabah MIT Ibnu Mas'ud Yogyakarta.

Metodologi berarti ilmu pengetahuan yang mempelajari tentang cara- cara atau jalan yang ditempuh untuk mencapai suatu tujuan untuk hasil yang efektif, karena penguasaan materi saja tidaklah mencukupi. Diperlukan penguasaan beberapa metode belajar agar proses belajar mengajar berjalan dengan baik. Guru mata pelajaran kemampuan menulis bahasa Arab menggunakan metode yang beragam dalam melaksanakan kegiatan belajar mengajar. Metode belajar yang dimaksud adalah:

1) Metode Gramatika dan Terjamah. Strategi ini diterapkan oleh guru mata pelajaran kemampuan menulis bahasa Arab di kelas V, pada saat itu materi yang diberikan adalah Mengenal Alif lam ta'rif dan penulisan yang bersambung dengan huruf ma'ani (misal min, ila, dan seterusnya). Dimana metode ini ditujukan kepada peserta didik agar lebih mampu menulis dan membaca naskah berbahasa Arab atau karya sastra. Arab dan memiliki nilai disiplin serta pengembangan intelektual. Gambaran pembelajarannya sebagai berikut:

Dalam pembelajaran kemampuan menulis bahasa Arab ini guru masuk kelas dan membuka kelas dengan salam dan bertanya kabar kemudian penyampaian materi dengan metode gramatika dan terjamah yaitu menghafal kaidah-kaidah Alif lam ta"rif dan penulisan yang bersambung dengan huruf ma"ani menggunakan bahasa Arab kemudian mengajarkan terjemahan dari kaidah-kaidah tersebut. Siswa kemudian mencatat jika perlu. Terkadang penyampaian materi dengan audio-visual serta penjelasan lisan dan tulisan di papan tulis. Setelah penyampaian materi dan siswa memahami dengan baik barulah pemberian soal.

Analisis dalam strategi ini menurut peneliti cukup baik karena 
tanpa disadari siswa memperoleh pengetahuan dari keduanya (gramatika dan terjemah) dengan pengetahuan menjadi utuh, siswa lancar bercakap-cakap dan berkonunikasi dengan bahasa Arab serta menuliskannya dengan kaidah-kaidah yang benar.

2) Metode Langsung. Metode langsung menekankan bahwa pembelajaran bahasa dengan cara interaksi langsung dalam bahasa Arab dalam situasi- situasi yang bermakna. Asumsi metode langsung adalah proses belajar bahasa target sama dengan belajar bahasa sumber, yakni penggunaan bahasa secara langsung dan intensif dalam komunikasi. . Dalam pembelajaran kemampuan menulis bahasa Arab di MIT Ibnu Mas"ud di kelas V dengan materi kaidah-kaidah penulisan alif lam qomariyyah dan alif lam syamsyiyyah. Dimana guru memulai pembelajaran dengan mengucapkan salam dan menanyakan kabar menggunakan bahasa Arab, guru menjelaskan kaidah-kaidah penulisan alif lam qomariyyah dan alif lam syamsyiyyah langsung dengan bahasa Arab dengan sedikit memberikan arti penjelasan di akhir materi.

Seperti yang terjadi dalam pembelajaran pada umumnya, adakalanya siswa bosan dan asik mengobrol sendiri dengan teman sebangkunya, maka guru memberikan kuis terkait materi tersebut dengan tetap menggunakan bahasa Arab sehingga siswa tidak bosan. Analisis dalam strategi ini menurut peneliti cukup baik karena menjadikan siswa terampil menyimak dan memiliki banyak kosakata serta menguasai tata bahasa sehingga mampu membedakan isim, fiil dan huruf dengan baik. Karena kemampuan membedakan isim, fiil serta huruf berpengaruh pada kemampuan menulis bahasa Arab itu sendiri.

3) Metode Resitasi (Tugas). Metode resitasi merupakan metode penyajian bahan, dimana guru memberikan tugas tertentu agar siswa melakukan kegiatan belajar yang dapat dilakukan di luar jam pembelajaran di di MIT Ibnu Mas"ud, tugas bisa diberikan di halaman sekolah dan lain-lain. Metode ini diterapkan ketika guru memberikan tugas menebalkan tulisan Al-Qur"an dengan buku Follow The Line, dan menghafal kaidah-kaidah penulisan yang ada dalam rumus rumus kaidah merangakai huruf-huruf terpisah dan bersambung.

Tugas menghafal kaidah-kaidah penulisan dan menulis Al- 
Qur'an dengan buku Follow The Line yang relevan dengan pembelajaran hari itu. Kedua metode tersebut cukup baik diterapkan untuk peningkatan kemampuan menulis bahasa Arab siswa, karena waktu lebih efisien dan siswa bisa mudah menerima materi baru yang akan disampaikan di kelas karena telah menghafal kaidah- kaidah penulisan sebelumnya.

Analisis dalam metode ini cukup baik untuk peningkatan kemampuan menulis bahasa Arab siswa secara maksimal. Dalam penerapan metode resitasi ini guru memantau proses penuntasan tugas dengan memberikan arahan dan nilai pada akhir pembelajaran.

4) Metode Dikte/Imla'. Bahan pelajaran yang biasa didektekan, antara lain kata, kalimat sederhana, atau bacaan singkat. Strategi ini diterapkan oleh guru pembelajaran di kelas $\mathrm{V}$ dengan materi yang telah mereka tulis sebelumnya di buku menulis Al- Qur'an Follow The Line. Jadi setelah siswa menulis beberapa baris ayat al-Qur'an, guru mendikte ayat tersebut dengan beberapa pengulangan. Setelah diadakan imla' maka guru mengadakan koreksi bersama terkait penulisan siswa hari itu. Jika banyak siswa yang masih keliru dalam penulisan, maka pekan berikutnya materi tersebut akan diulang dan tidak menambah materi baru sampai siswa betul-betul paham. Analisis dalam metode ini cukup baik, karena Tujuan metode imla' adalah supaya siswa paham betul kaidah-kaidah penulisan yang telah dipelajari dan mengevaluasi seberapa penyerapan siswa terhadap apa yang mereka tulis.

d. Unsur-unsur yang digunakan dalam pembelajaran kemampuan menulis bahasa Arab MIT Ibnu Mas'ud Yogyakarta.

1) Lingkungan Fisik

Lingkungan fisik adalah seluruh aspek fisik yang ada di lingkungan sekolah. Di MIT Ibnu Mas'ud Yogyakarta lingkungan fisik tersebut meliputi ruang kelas yang kondusif, peralatan belajar serta sarana prasana penunjang yang lain. Hal lain adalah lokasi MIT Ibnu Mas'ud Godean terletak di dekat sawah dan jauh dari jalan besar sehingga membuat pembelajaran lebih fokus dan tenang. 
2) Lingkungan Sosial

Lingkungan sosial merupakan tempat berlangsungnya bermacammacam interaksi sosial dalam lingkup individu maupun kelompok. Dalam hal ini lingkungan sosial yang menunjang pembelajaran kemampuan menulis bahasa Arab adalah adanya pembiasaan berbahasa Arab setiap harinya. Baik ketika guru memulai pelajaran maharah kitabah ataupun kosakata sehari-hari.

3) Penyajian Pembelajaran

Guru maharah kitabah menggunakan satu teknik dalam menyampaikan materi yaitu teknik penemuan.

Teknik penemuan adalah memperdalam keterlibatan pembelajar dengan konten materi. Teknik ini melibatkan seluruh pembelajar, langkah-langkah yang berulang, kendali pembelajar atas pembelajaran. Teknik ini merupakan proses dimana seorang siswa melakukan proses pembelajaran yang harus mampu mengasimilasikan sesuatu konsep atau prinsip. Yang dimaksud proses pembelajaran ialah mengamati, mencerna, mengerti menggolong-golongkan, membuat dugaan membuat kesimpulan dan lain sebagainya. Sedangkan prinsip ialah siswa dibiarkan menemukan sendiri atau mengalami pembelajaran itu sendiri, guru hanya membimbing dan memberikan instruksi.

Dalam pembelajaran kemampuan menulis bahasa Arab, sebelum guru menerapkan teknik ini, guru memberitahukan terlebih dahulu materi yang akan dipelajari hari itu, kemudian guru memberikan teknik penemuan ini untuk melatih kemandirian siswa dan memberikan kepada siswa untuk berkembng maju sesuai dengan kemampuan masing-masing. Respon siswa ketika teknik ini diterapkan sejauh ini bisa memahami dengan baik dengan sedikit instruksi ringan dari guru.

4) Materi Pembelajaran

Materi pembelajaran adalah bentuk bahan atau seperangkat substansi pembelajaran untuk membantu guru dalam kegiatan belajar mengajar yang disusun secara sistematis dalam rangka memenuhi standar kompetensi yang ditetapkan. Penelitian dilakukan di kelas V dengan materi yang diberikan adalah buku Pintar Menulis 
Arab jilid 4 meliputi:

a) Merangakai 3 huruf atau lebih;

b) Mengenal Ta' marbuthoh;

c) Mengenal Alif lam ta'rif dan penulisan yang bersambung dengan huruf ma'ani (misal min, ila, dan seterusnya).

d) Mengenal bentuk-bentuk huruf di depan, di tengah dan di belakang kata. Sedangkan materi buku Al Qur"an Tulis metode Follow The Line adalah menebalkan juz 29 1/2 kedua.

5) Proses Pembelajaran

Proses pembelajaran adalah proses yang di dalamnya terdapat kegiatan antara guru-siswa dan komunikasi timbal balik yang berlangsung dalam situasi edukatif untuk mencapai tujuan belajar. Dalam proses pembelajaran, guru dan siswa merupakan dua komponen yang tidak bisa dipisahkan. Sesuai dengan hasil observasi peneliti pada saat kegiatan belajar berlangsung, proses pembelajaran di MIT Ibnu Mas'ud Godean di kelas V adalah sebagai berikut:

Pembelajaran ini berlangsung selama satu jam pelajaran (45 menit). Guru memulai pelajaran dengan mengucapkan salam pembuka, menanyakan kabar kepada para siswa dengan bahasa Arab, kemudian guru mengabsen siswa satu persatu. Setelah mengabsen, guru mengulang materi belajar yang telah dipelajari pekan lalu dengan metode tanya jawab. Kemudian jika memulai materi baru guru memberikan pre test untuk melihat kemamapuan siswa, setelah pre test guru mulai menyampaiakan materi dengan metode langsung yaitu dengan bahasa Arab dan memberikan sedikit terjemahan pada kata yang tidak dipahami siswa. Materi yang diberikan fleksibel, bisa jadi dalam satu pekan hanya menebalkan, kemudia pekan kedua menebalkan lagi, lalu pekan ketiga imla' dan pekan keempat adalah evaluasi imla'.

Sebelum memberikan tugas, guru memberikan kesempatan siswa bertanya tentang materi yang belum dipahami. Kemudian memberikan tugas berupa menebalkan Al Qur"an Tulis metode Follow The Line kurang lebih 7 baris lalu mengoreksi. Ketika menebalkan selesai 1 halaman maka peremuan berikutnya dijadwalkan sebagai imla' dengan materi yang telah ditebalkan siswa pekan-pekan lalu. 
Adanya imla' ini penting karena untuk mengevaluasi seberapa penyerapan siswa terhadap apa yang mereka tulis. Kemudian dari evaluasi imla' ini didapatkan bahwa ada beberapa siswa yang kurang teliti dalam merangkai huruf atau pembelajaran merangkai mereka. Setelah melihat hasil evaluasi siswa, dapat disimpulkan bahwa ada sebagian siswa yang masih belum paham tentang kaidah alif lam qomariyyah atau alif lam syamsyiyyah ada juga yang masih belum paham membedakan huruf dan makhroj huruf (tempat keluar huruf). maka nanti materi itu akan diulangi lagi sampai mereka paham betul terkait penulisan alif lam atau makhroj huruf. Setelah kegiatan belajar selesai guru menutup dengan doa kafarotul majelis lalu mengucapkan salam.

2. Faktor-faktor Pendukung dan Penghambat Pembelajaran maharah kitabah di Madrasah Ibtidaiyyah Ibnu Mas'ud Godean Yogyakarta.

a. Faktor pendukung Pembelajaran Maharah Kitabah.

Faktor pendukung merupakan sesuatu yang sifatnya menyokong atau menunjang pembelajaran maharah kitabah. Diantara faktor-faktor pendukung yang dapat menunjang keberhasilan pembelajaran kemampuan menulis bahasa Arab di MIT Ibnu Mas'ud Godean adalah:

1) Dukungan kepala sekolah

Dukungan adalah suatu upaya yang diberikan kepada seseorang baik itu moril maupun material untuk memotivasi orang lain dalam melaksanakan suatu kegiatan. Dukungan dari kepala sekolah berupa mata pelajaran kemampuan menulis bahasa Arab ini dimasukkan tersendiri dalam kurikulum sekolah, tidak menyatu dengan mata pelajaran bahasa Arab. Sehingga diharapkan siswa mampu menguasai kemampuan menulis bahasa Arab dengan baik sesuai kaidah yang benar. $^{7}$

2) Lingkungan yang kondusif Lingkungan yang kondusif yaitu suasana yang nyaman dan menyenangkan. Nyaman dalam hal ini jauh dari gangguan suara dan bunyi yang merusak konsentrasi belajar karena lokasi MIT Ibnu Mas'ud Godean terletak di dekat sawah dan jauh dari jalan besar. Faktor lainnya yang mendukung adalah adanya pembiasaan berbahasa Arab setiap

7 Hasil wawancara dengan Niken Widoresmi, Pengelola Madrasah Ibtidaiyyah Tahfizh Ibnu Mas"ud Godean, tanggal 19 Agustus 2020. 
harinya sehingga siswa tidak asing dengan kosakata Arab serta bentuk penulisannya. 8

3) Menulis bahasa Arab sebagai punishment yang mendidik Menulis bahasa Arab/menulis beberapa ayat dalam al-Qur"an sebagai punishment ketika siswa melanggar atau berbuat kesalahan. Pemberian punishment tersebut tergantung tingkat kesalahan siswa tersebut. Dengan memberi punishment menulis bahasa Arab/ayat al- Qur"an bukan berarti sesuatu hal yang buru, tetapi sebagai pengganti kesalahn tersebut dengan kebaikan.

4) Adanya sistem Tahajji

Tahajji adalah membaca Al-Qur"an dengan mengeja huruf perhuruf beserta hukum-hukumnya. Dengan adanya sistem Tahajji ini membuat para siswa terbiasa melihat rangkaian huruf dalam al- Qur"an serta mempermdah dalam penyampaian materi.

b. Faktor penghambat Pembelajaran Kemampuan Menulis Bahasa Arab.

1) Adanya siswa pindahan dari sekolah lain sehingga belum mengerti kaidah dalam penulisan bahasa Arab.

2) Beberapa siswa masih sering lupa kaidah-kaidah merangakai huruf- huruf Arab sehingga guru harus mengulang-ulang kaidah tersebut dan memakan waktu yang lama.

3) Siswa kurang serius dalam mengerjakan dan terburu-buru ingin cepat selesai.

4) Belum adanya media LCD atau proyektor untuk pembelajaran kemampuan menulis bahasa Arab dan masih menggunakan media buku-buku paket saja dengan metode klasikal.

\section{KESIMPULAN}

Berdasarkan analisis hasil penelitian, maka dapat disimpulkan, pertama, Pembelajaran Kemampuan Menulis Bahasa Arab Di Madrasah Ibtidaiyyah Ibnu Mas'ud Godean Yogyakarta yang terdiri: 1) Tujuan pembelajaran kemampuan menulis bahasa Arab adalah Merupakan kewajiban seorang muslim adalah belajar membaca dan menulis dengan kaidah yang benar, kemudian siswa mampu menguasai kaidahkaidah penulisan bahasa Arab dengan baik. Kelak jika harus berada di majlis ulama bisa menulis Arab sesuai dengan materi yang dibawakan, terakhir siswa mampu menulis Arab jika didektekan atau didengarkan; 2) Metode yang digunakan dalam

\footnotetext{
${ }^{8}$ Hasil Wawancara Dengan Siti Nurul Hidayah, Guru Kemampuan Menulis Bahasa Arab, Tanggal 29 November 2019
} 
pembelajaran kemampuan menulis bahasa Arab MIT Ibnu Mas'ud Yogyakarta cukup baik, guru menggunakan metode gramatika dan terjemah, metode langsung, metode resitasi (tugas) dan metode imla'/dikte, 3) Media yang digunakan dalam pembelajaran kemampuan menulis bahasa Arab MIT Ibnu Mas'ud Yogyakarta cukup baik, dengan menggunakan media berupa 4 paket Buku Pintar Menulis Arab karya Fajriyah Na'im S.S, buku paket Al Qur'an Tulis metode Follow The Line, buku panduan imla' karya Muhammad Magdur, rumus kaidah merangkai huruf, papan tulis, dan spidol, 4) Unsurunsur pembelajaran kemampuan menulis bahasa Arab MIT Ibnu Mas'ud Yogyakarta adalah lingkungan fisik meliputi ruang kelas yang kondusif, peralatan belajar serta sarana prasana penunjang yang lain. Lingkungan sosial berupa pembiasaan berbahasa Arab sehari-hari. Penyajian pembelajaran yang cukup baik, guru menggunakan teknik penemuan. Materi pembelajaran berupa Merangkai 3 huruf atau lebih, mengenal $\mathrm{Ta}^{\prime}$ marbuthoh, Mengenal Alif lam ta'rif dan penulisan yang bersambung dengan huruf ma'ani (misal min, ila, dan seterusnya), mengenal bentuk-bentuk huruf di depan, di tengah dan di belakang kata, dan proses pembelajaran dengan cukup baik.

Kedua, faktor pendukung dan penghambat Pembelajaran Maharah Kitabah diantaranya: a) Faktor pendukung pembelajaran kemampuan menulis bahasa Arab yaitu: dukungan kepala sekolah, sarana pembelajaran yang menunjang, lingkungan yang kondusif, menulis bahasa Arab sebagai punishment yang mendidik, adanya tahajji (membaca al-Qur'an dengan mengeja perhuruf); b) Faktor penghambat pembelajaran Maharah Kitabah adalah adanya siswa pindahan dari sekolah lain sehingga guru harus mengulang kaidah tersebut dan memakan waktu lama, siswa kurang serius dan terburu-buru ingin cepat selesai, belum adanya media LCD atau proyektor untuk pembelajaran maharah kitabah dan masih menggunakan media buku-buku paket saja dengan metode klasikal.

\section{DAFTAR PUSTAKA}

Acep Hermawan. 2011. Metodologi Pembelajaran Bahasa Arab. Bandung: PT. Remaja Rosdakarya.

Ahmad Izzan. 2009. Metodologi Pembelajaran Bahasa Arab. Bandung: Humaniora. Ahmad Muradi. 2016. Pembelajaran Menulis Bahasa Arab: dalam Perspektif Komunikatif. Jakarta: Kencana.

Albi Anggito dan Johan Setiawan. 2018. Metode Penelitian Kualitaif. Sukabumi: CV Jejak.

Aziz Fakhrurrozi dan Erta Mahyudin. 2012. Pembelajaran Bahasa Arab. Jakarta Pusat: Direktoral Jenderal Pendidikan Islam Kementrian Agama.

Batmang. 2019. Potret Pembelajaran Bahasa Arab di Pesantren Gontor VII Indonesia. Yogyakarta: Deepublish. 
Conny R. Semiawan. 2011. Metode Penelitian kualitatif. Jakarta: Grasindo Darmadi. 2012. Pengembangan Model dan Metode Pembelajaran Dalam Dinamika Belajar Siswa, Yogyakarta: Deepublish, 2012

Syaiful Bahri Djamarah. 2002. Psikologi Belajar. Jakarta: PT. Rineka cipta.

Hasan Saefulloh. 2012. Teknik Pembelajaran Keterampilan Bahasa Arab. Cirebon: CV.Pangger.

Hasan Syahatah. 2002. Ta"lim al Lughah al-„arabiyyah Baina an-Nazhariyyah wa at Tathbiq. al Qahirah: al-Dar al-Mashriyah al-Lubnaniyah.

H. Asis Saefuddin dan Ika Berdiati. 2016. Pembelajaran Efektif. Bandung: PT. Remaja Rosdakarya.

Ismail Suardi Wekke. 2014. Model Pembelajaran Bahasa Arab. Yogyakarta: Deepublish.

Lilik Huriyah. 2016. Peran Perpustakaan Keluarga dalam meningkatkan minat dan keterampilan membaca anak. Journal of Islamic Education Studies. UIN Sunan Ampel Surabaya. Volume I, Nomor 1.

Mahmud Kamil an Naqah. 1985. Ta"lim Lughah al Arabiyah Lin-Nathiqin bilughatin Ukhra. Mekkah: Jamiah Ummul Qura.

Munir. 2016 Perencanaan Sistem Pengajaran Bahasa Arab. Jakarta: Kencana Prenadamedia Group.

M. Feri Fauzi dan Irma Anindiati. 2020. E-Learning Pembelajaran bahasa Arab. Malang: Penerbit UMM.

M.Iqbal Hasan. 2002. Pokok-pokok Materi Metodologi Penelitian dan aplikasinya, Bogor: Ghalia Indonesia.

M. Khalilullah. Pembelajaran Bahasa Arab aktif (kemahiran Istima" dan Takallum). Jurnal Sosial Budaya. Jakarta. volume VIII, nomor 2.

M. Yunus Aris dan Arifuddin. 2020. Panduan Menulis Kreatif. Yogyakarta: Deepublish.

Ni"matuzzuhroh. 2018. Observasi: Teori Dan Aplikasi Dalam Psikologi, Malang: Penerbit UMM.

Oktavia Ratnaningtyas. 2015. Pembelajaran Menulis Bahasa Arab di Program Khusus Perkuliahan Bahasa Arab (PKBA). Tafaqquh. UIN Malang. Volume III nomor 2.

Pawito. 2007. Penelitian Komunikasi Kualitatif, Yogyakarta: LkiS Yogyakarta.

Rahmi Ramadhani dan lainnya. 2020. Belajar Dan Pembelajaran: Konsep Dan Pengembangan, Medan: Yayasan Kita Menulis

Syaiful Bahri Djamarah, Aswan Zain. 2010. Strategi Belajar Mengajar. Jakarta: Gaung Persada Press.

Syafaruddin. 2012. Pendidikan dan Pemberdayaan Masyarakat. Medan: Perdana Publishing.

Siti Kuraedah. 2015. Aplikasi Maharah Kitabah Dalam Pembelajaran Bahasa Arab. Al Ta"dib. IAIN Kediri. Volume 8, nomor 2. 
Sugiyono. 2013. Metode Penelitian Kombinasi (Mixed Methods). Bandung: Alfabeta.

Suharso, Ana Retnoningsih. 2005 Kamus Besar Bahsa Indonesia Edisi Lur, Semarang: CV. Widya Karya.

Sulastri. 2016. Pengembangan media pembelajaran Arabic Thematic Video pada keterampilan berbicara bagi siswa kelas VIII MTS. Journal of Arabic Learning and Teaching. Semarang. Volume V nomor 1.

Suwardi Endraswara. 2006. Metode, Teori, Teknik Penelitian Kebudayaan. Yogyakarta: Pustaka Widyatama.

Umrati dan Hengki Wjaya. 2020. Analisis Data Kalitatif. Makassar: Sekolah Tinggi Theologia Jaffray. 
